\title{
Endocrine Function in Acute Triton-induced Hyperlipidaemic Rats after Being Administered Aqueous Fruit Extract of Solanum macrocarpum, $\alpha$-Solanidine and Standard Hypolipidaemic Agents
}

\author{
O. A. Sodipo ${ }^{1}$, F. I. Abdulrahman ${ }^{2}$, U. K. Sandabe ${ }^{3} \&$ B. Wampana ${ }^{3}$ \\ ${ }^{1}$ Department of Clinical Pharmacology and Therapeutics, College of Medical Sciences, University of Maiduguri, \\ Maiduguri, Nigeria \\ ${ }^{2}$ Department of Chemistry, Faculty of Science, University of Maiduguri, Maiduguri, Nigeria \\ 3 Department Veterinary Physiology, Pharmacology and Biochemistry, Faculty of Veterinary Medicine, \\ Maiduguri, Nigeria
}

Correspondence: O. A. Sodipo, Department of Clinical Pharmacology and Therapeutics, College of Medical Sciences, University of Maiduguri, Maiduguri, Nigeria. Tel: 234-803-410-7098. E-mail: sodipoolufunke@yahoo.com

Received: December 7, 2012 Accepted: December 28, 2012 Online Published: December 30, 2012

doi:10.5539/jps.v2n1p110 URL: http://dx.doi.org/10.5539/jps.v2n1p110

\begin{abstract}
Experimental studies were carried out on the effect of Solanum macrocarpum, $\alpha$-Solanidine (a glycoalkaloid found in the Solanaceae), three antihyperlipidaemic drugs (nicotinic aid, simvastin and cholestyramine) on forty two (42) male rats made hyperlipidaemic by treating them with $400 \mathrm{mg} / \mathrm{kg}$ triton-X for 7 days. The rats were divided into 7 groups of 6 rats each. At $24 \mathrm{~h}, 48 \mathrm{~h}$ and $72 \mathrm{~h}$ respectively, the rats in each group were humanely sacrificed and blood samples collected for endocrine function analysis which included thyroid hormones (thyroxine or $\mathrm{T}_{4}, 3,5,3$ - triiodothyronine or $\mathrm{T}_{3}$ and thyroid stimulating hormone or TSH), sex hormones (testosterone and $17 \beta$ oestradiol) and the pancreatic hormone, insulin. Changes in $T_{3}, T_{4}$, oestradiol, testosterone and insulin were significant $(p<0.05)$ throughout the period of study. There was no change in the TSH values $(p>0.05)$ throughout the period of study. For the extract, $T_{3}$ significantly increased $(p<0.05)$ from $0.60 \pm 0.14 \mathrm{ng} / \mathrm{mL}$ to $0.65 \pm 0.13 \mathrm{ng} / \mathrm{mL}$ and then decreased to $0.55 \pm 0.21 \mathrm{ng} / \mathrm{mL}$ at $24 \mathrm{~h}, 48 \mathrm{~h}$ and $72 \mathrm{~h}$ respectively. For $\alpha$-Solanidine and the three hypolipidaemic drugs, $T_{3}$ values were too small to be measured i.e. $<0.20 \mathrm{ng} / \mathrm{mL}$. For the extract, $\mathrm{T}_{4}$ significantly increased $(\mathrm{P}<0.05)$ from $3.60 \pm 0.5 \mu \mathrm{g} / \mathrm{dL}$ to $4.30 \pm 0.43 \mu \mathrm{g} / \mathrm{dL}$ and then decreased to $3.80 \pm 0.28 \mu \mathrm{g} / \mathrm{dL}$ at $24 \mathrm{~h}, 48 \mathrm{~h}$ and $72 \mathrm{~h}$ respectively. For $\alpha$-solanidine and the three hypolipidaemic drugs, the $\mathrm{T}_{4}$ values at $24 \mathrm{~h}$ were $4.00 \pm 0.00 \mu \mathrm{g} / \mathrm{dL}$, whilst the values remained the same at $48 \mathrm{~h}$ and $72 \mathrm{~h}$ i.e. there was no change. For testosterone, oestradiol and insulin, the values of the negative control were higher than those of the positive control. For the extract, the oestradiol values significantly increased $(\mathrm{P}<0.05)$ from $18.00 \pm 4.24 \mathrm{pg} / \mathrm{mL}$ to $19.50 \pm 4.24 \mathrm{pg} / \mathrm{mL}$, then decreased to $15.04 \pm 4.24 \mathrm{pg} / \mathrm{mL}$ at $24 \mathrm{~h}, 48 \mathrm{~h}$ and $72 \mathrm{~h}$ respectively. For $\alpha$-solanidine and the three hypolipidaemic drugs, the values of oestradiol were too small to be measured i.e. $<5.00 \mathrm{pg} / \mathrm{mL}$. For the extract, the testosterone level was $0.20 \pm 0.07 \mathrm{ng} / \mathrm{mL}$ at $24 \mathrm{~h}, 0.20 \pm 0.00 \mathrm{ng} / \mathrm{mL}$ at $48 \mathrm{~h}$ and $<0.20 \mathrm{mg} / \mathrm{mL}$ at $72 \mathrm{~h}$, i.e. the value could not be measured. For the other four agents, the level of testosterone was $<0.20 \mathrm{ng} / \mathrm{mL}$ i.e. too low to be measured. For the extract, the insulin values significantly decreased $(\mathrm{p}<0.05)$ from $2.00 \pm 0.00 \mu \mathrm{U} / \mathrm{mL}$ to $1.00 \pm 0.00 \mu \mathrm{U} / \mathrm{mL}$ and $<1.00 \mu \mathrm{U} / \mathrm{mL}$ (i.e. too low to be measured) at $24 \mathrm{~h}, 48 \mathrm{~h}$ and $72 \mathrm{~h}$ respectively. On administration of $\alpha$-solanidine, NA, cholestyramine and simvastatin the insulin levels remained almost constant throughout the period of study. For $\alpha$-solanidine, the values were $1.50 \pm 0.00 \mu \mathrm{U} / \mathrm{mL}, 2.00 \pm 0.00 \mu \mathrm{U} / \mathrm{mL}$ and $2.00 \pm 0.00 \mu \mathrm{U} / \mathrm{mL}$ at $24 \mathrm{~h}, 48 \mathrm{~h}$ and $72 \mathrm{~h}$ respectively. For NA, the insulin level remained at $2.00 \pm 0.00 \mu \mathrm{U} / \mathrm{mL}$ throughout the study period, for cholestyramine, the insulin values were $2.00 \pm 0.00 \mu \mathrm{U} / \mathrm{mL}$ and $1.00 \pm 0.00$ $\mu \mathrm{U} / \mathrm{mL}$ at $24 \mathrm{~h}, 48 \mathrm{~h}$ and $72 \mathrm{~h}$ respectively whilst simvastatin had insulin values of $1.50 \pm 0.00 \mu \mathrm{U} / \mathrm{mL}, 2.00 \pm 0.00$ $\mu \mathrm{U} / \mathrm{mL}$ and $2.25 \pm 0.50 \mu \mathrm{U} / \mathrm{mL}$ at $24 \mathrm{~h}, 48 \mathrm{~h}$ and $72 \mathrm{~h}$ respectively. The aqueous fruit extract of $S$. macrocarpum when compared to $\alpha$-solanidine, cholestyramine, simvastatin and NA under the condition of study, was probably more effective in lowering hyperlipidaemia in triton-induced hyperlipidaemic rats as the fruit is a combination of active principles whilst the other four (4) substances single entities.
\end{abstract}

Keywords: Solanum macrocarpum, aqueous extract $\alpha$-solanidine, hypolipidaemic drugs, endocrine function, 
hyperlipidaemic rats

\section{Introduction}

In the traditional North East Arid Zone of Nigeria, the unripe fruit of S. macrocarpum (synonyms: $S$. macrocarpum L. senso stricto and $S$. daysphyllum Schumach \& Thonn) (Grubben \& Denton, 2004) called "Gorongo" in Kanuri is known for its laxative, antihypertensive and hypolipidaemic effects. Importantly, $S$. macrocarpum had been shown to display a wide spectrum of biological activities. There are experimental data to support the ethnopharmacological use of this plant in traditional medicine (Sodipo et al., 2009a).

Recently, hepatoprotective effect has been demonstrated with the aqueous fruit extract of S. macrocarpum in diet-induced hypercholesterolaemic rats (Sodipo et al., 2009b) and acute triton-induced hyperlipidaemic rats respectively (Sodipo et al., 2011). Sodipo et al. (2012) found the levels of endocrine function indices-thyroid hormones $\left(\mathrm{T}_{3}, \mathrm{~T}_{4}, \mathrm{TSH}\right)$, reproductive hormones (testosterone and $17 \beta$ oestradiol) and insulin (the pancreatic hormones) to be increased under the conditions of the study, probably contributing to the lipid lowering effect of the plant. However, the mechanism of hypolipidaemia has not been extensively studied.

Most of the current drugs that lower hyperlipidaemia have serious toxicities and are not cost effective. In an attempt to find alternatives to the existing hypolipidaemic drugs, the present study compared the ability of the aqueous fruit extract of $S$. macrocarpum to lower hyperlipidaemia with that of $\alpha$-solanidine (a glycoalkaloid found in the Solanaceae and said to lower hyperlipidaemia), (Anonymous a, 2007) and three hypolipidaemic drugs, namely NA (NA), simvastatin (SV) and cholestyramine (CT).

\section{Materials and Methods}

\subsection{Plant Collection and Identification}

The plant material (Solanum macrocapum Linn.) used in this study was obtained from Alau in Konduga Local Government, Borno State, Nigeria, between October and November, 2007. The plant was identified and authenticated by Prof. S.S. Sanusi of the Department of Biological Sciences, University of Maiduguri, Maiduguri, Nigeria. Specimen voucher No. 548 was deposited at the Research Laboratory of the Department of Chemistry.

\subsection{Extraction}

The fruit of $S$. macrocarpum with the calyx removed was air dried and pulverized by using pestle and mortar. The $2.2 \mathrm{~kg}$ of the ground fruit was subjected to exhaustive Soxhlet-extraction in $3 \mathrm{~L}$ distilled water at $100{ }^{\circ} \mathrm{C}$ to give the extract yield $15.3 \% \mathrm{w} / \mathrm{w}$ (Mittal et al., 1981; Fernando et al., 1991; Lin et al., 1999). The resultant solution was concentrated in vacuo and it was stored in a specimen bottle and kept in a desiccator at room temperature until when required.

\subsection{Animals and Treatment}

Forty two (42) male albino rats of Wistar strain weighing 86-182g were used in this study. The animals were obtained from the Animal House Unit of the Department of Veterinary Physiology and Pharmacology, University of Maiduguri. The animals were housed under standard laboratory condition in plastic cages. They were fed commercial grower's mash feed (ECWA, Feeds, Jos, Nigeria) and water was provided ad libitum. All the animals were handled according to the International Guiding Principles for Biomedical Research Involving Animals (CIOMS, 1985) as certified by the Animal Ethics Committee of the Faculty of Veterinary Medicine, University of Maiduguri (Approved on October $15^{\text {th }}, 2008$ at its $12^{\text {th }}$ Ethical Committee Meeting). The animals were randomly distributed into seven groups of 6 rats per group.

Group one:

Group two:

Group three:

Group four:
Rats in this group served as the negative control. They were fed with normal feed diet and given water ad libitum

Rats in this group served as the positive control. They were fed with normal diet and given water ad libitum. They were also administered $400 \mathrm{mg} / \mathrm{kg}$ triton-X orally (p.o) for 1 week to make them hyperlipidaemic.

Rats in this group were fed with normal feed diet and given water ad libitum; administered $400 \mathrm{mg} / \mathrm{kg}$ triton-X p.o. for 1 week and then given $50 \mathrm{mg} / \mathrm{kg}$ aqueous fruit extract of $S$. macrocarpum i.p. from a stock concentration of 200 $\mathrm{mg} / \mathrm{mL}$ (2 $\mathrm{g}$ extract dissolved in $10 \mathrm{~mL}$ distilled water)

Rats in this group were fed with normal feed diet and given water al libitum, administered $400 \mathrm{mg} / \mathrm{kg}$ triton-X p.o. for 1 week and then given $50 \mathrm{mg} / \mathrm{kg}$ $\alpha$-solanidine i.p. - a steroidal glycoalkaloid that is found in the Solanaceae and 
Group five:

\section{Group six:}

\section{Group seven:}

is said to lower hyperlipidaemia (by dissolving $50 \mathrm{mg}$ of approximately $95 \%$ $\alpha$-solanine white powder, Sigma, USA in $1 \mathrm{~mL}$ distilled water $\mathrm{H}_{2} \mathrm{O}$ to give a stock concentration of $50 \mathrm{mg} / \mathrm{mL}$ )

Rats in this group were fed with normal feed diet, given water ad libitum, 400 $\mathrm{mg} / \mathrm{kg}$ triton-X p.o. for 1 week and then given $50 \mathrm{mg} / \mathrm{kg}$ NA B.P. orally hypolipidaemic drug, from a stock concentration of $50 \mathrm{mg} / \mathrm{mL}$ (by dissolving $50 \mathrm{mg}$ white round tablet in $1 \mathrm{~mL}$ distilled water).

Rats in this group were fed with normal feed diet, given water ad libitum, $400 \mathrm{mg} / \mathrm{kg}$ triton-X p.o. for 1 week and then given $50 \mathrm{mg} / \mathrm{kg} \mathrm{CT} \mathrm{-} \mathrm{a}$ hypolipdaemic drug, (Questran, Bristol-Meyers Squibb) p.o. from a stock concentration of $100 \mathrm{mg} / \mathrm{mL}$ (dissolving $1 \mathrm{~g}$ powder in $10 \mathrm{~mL}$ distilled water)

Rats in this group were fed with normal feed diet, given water ad libitum, $400 \mathrm{mg} / \mathrm{kg}$ triton-X p.o. for 1 week and then given $50 \mathrm{mg} / \mathrm{kg} \mathrm{SV}-$ hypolipidaemic drug (Gimvastat-10, Stallion Lab, PVT Ltd, India, NAFDAC Reg. No. A4-0010 with sole agent as Pharmabase Nig. Ltd) p.o. from a stock concentration of $10 \mathrm{mg} / \mathrm{mL}$ (by dissolving $20 \mathrm{mg}$ light yellow film-coated tablets in $1 \mathrm{~mL}$ distilled water).

After administration of the extract, $\alpha$-solanidine and the three hypolipidaeic drugs to the rats in groups three-seven respectively, every $24 \mathrm{~h}$ for 3 consecutive days, 2 rats from each group (Groups one-seven) were humanely sacrificed and blood samples were collected for biochemical kidney analysis (Adapted from Williamson et al., 1996).

\subsection{Endocrine Function Tests}

Two rats from each of the groups were humanely sacrificed after $24 \mathrm{~h}, 48 \mathrm{~h}$ and $72 \mathrm{~h}$ respectively of the effect on acute hyperlipidaemic rats by cutting their throat with a sterile blade. Blood was collected into clean, sterile labeled centrifuge tubes without an anticoagulant and centrifuged at a rate of 12,000 revolutions per minute (rpm) for 10 minutes. The clear, yellow serum was then separated from settled cellular elements and subjected to determination of endocrine function tests.

The endocrine function tests estimated from the serum were thyroid hormones (which included 3, 5, 3' triiodothyronine or $\mathrm{T}_{3}, 3,5,3^{\prime}, 5^{\prime}$ tetraiodothyronine or $\mathrm{T}_{4}$ thyroid stimulating hormone, TSH) reproductive hormones (which include testosterone and $17 \beta$-oestradiol) and insulin.

$\mathrm{T}_{3}$ was determined by the Enzyme Link Immunosorbent Assay (Microwell Elisa) using competitive enzyme immunoassay reaction as described by Chopra et al. (1971b). $\mathrm{T}_{4}$ also called thyroxine was also determined by Enzyme Linked Immunosorbent Assay (Microwell Elisa) method using monoclonal antibodies specific for $\mathrm{T}_{4}$ as described by Chopra et al. (1971a). TSH called thyrotrophin was determined by the enzyme Linked Immunosorbent Assay (Elisa) method for the quantitative determination in serum as described by Hopton and Harrap, (1986); Bravermann (1996); Fisher (1996) was used for the determination of testosterone and that desribed by Tsang et al. (1980) was used for oestrogen determination. Insulin determination was carried out by the immunoenzymometric assay described by Sood (2006).

\subsection{Determination of Total Cholesterol}

Two rats in each group were humanely sacrificed by cutting the throat with a sterile blade. Blood was collected from the vena cava into clean, labelled centrifuge tubes without anticoagulant after the extract had been allowed to act for $24 \mathrm{~h}, 48 \mathrm{~h}$ and $72 \mathrm{~h}$ respectively. The blood was centrifuged at a rate of 12,000 rotations per minute (rpm) for 10 minutes. The clear, yellow serum was then separated from settled cellular elements. Cholesterol was assayed by Tindar's reaction (Evans \& Stein, 1986; NIH, 1990) using commercial kits, from Fortress Diagnostic Ltd, Antrim.

\subsection{Statistical Analysis}

Test of significance between control and treatment means were carried out by Analysis of Variance (ANOVA) and Student t-test using Graph Pad Software (1998).

\section{Results}

\subsection{Change in Mean Body Weight of Male Albino Rats after Being Administered Orally with Triton-Xfor 7 Days}

The effect of triton-X on mean body weight of albino rats fed orally with triton-X is shown in Table 1 . There was 
an increase in body weight of the rats in group one, two and five $(\mathrm{p}<0.05)$ when compared to day zero (i.e. when no triton- $\mathrm{X}$ was administered).

Table 1. Change in body weight of male albino rats after being administered orally with triton-X $(400 \mathrm{mg} / \mathrm{kg})$ for 7 days

\begin{tabular}{clc}
\hline \multirow{2}{*}{ Group } & \multicolumn{2}{c}{$\begin{array}{c}\text { Body Weight (g) } \\
\text { Days of Treatment }\end{array}$} \\
& 0 & 7 \\
\cline { 2 - 3 } & Mean \pm S. D. & $170.80 \pm 10.59^{\mathrm{b}}$ \\
One ${ }^{*}$ & $148.00 \pm 009.38^{\mathrm{a}}$ & $128.00 \pm 23.93^{\mathrm{a}}$ \\
Two & $117.80 \pm 26.68^{\mathrm{a}}$ & $166.00 \pm 4.58^{\mathrm{a}}$ \\
Three & $148.80 \pm 5.26^{\mathrm{a}}$ & $128.00 \pm 23.93^{\mathrm{a}}$ \\
Four & $117.80 \pm 26.60^{\mathrm{a}}$ & $173.00 \pm 42.57^{\mathrm{a}}$ \\
Five & $165.40 \pm 41.71^{\mathrm{a}}$ & $181.80 \pm 40.02^{\mathrm{a}}$ \\
Six & $164.80 \pm 38.75^{\mathrm{a}}$ & $100.00 \pm 18.56^{\mathrm{a}}$ \\
Seven & $86.60 \pm 16.10^{\mathrm{a}}$ &
\end{tabular}

Within rows, means with different superscripts are statistically significant $(\mathrm{p}<0.05)$ when compared to day zero (0) using student t-test.

0 day $=$ Before triton- $X$ administration.

$\mathrm{n}=6$ rats per group.

Group One* $=$ Rats fed with normal diet and had free access to water, but were not administered triton-X.

\subsection{Effect on Thyroid Hormones}

The results of the effect of the aqueous fruit extract of $S$. macrocarpum, $\alpha$-solanidine and the three hypolipidaemic drugs on thyroid hormones are shown in Table 2. There was no change in the TSH values ( $>$ $0.05)$ throughout the period of study. The $T_{3}$ and $T_{4}$ values were significant $(p<0.05)$ throughout the period of study. At 24, 48, $72 \mathrm{~h}, \mathrm{~T}_{3}$ for the aqueous fruit extract had the following values: $0.60 \pm 0.14 \mathrm{ng} / \mathrm{mL}, 0.65 \pm 0.13$ $\mathrm{ng} / \mathrm{mL}$ and $0.55 \pm 0.21 \mathrm{ng} / \mathrm{mL}$ respectively. The $\mathrm{T}_{3}$ values for $\alpha$-solanidine and the three hypolipidaemie drugs were $<0.20 \mathrm{ng} / \mathrm{mL}$ i.e. they were too small to be measured. Within the administration of the extract, the $\mathrm{T}_{4}$ value increased significantly $(\mathrm{p}<0.05)$ from $3.60 \pm 0.51 \mu \mathrm{g} / \mathrm{dL}$ at $24 \mathrm{~h}$ to $4.30 \pm 0.43 \mu \mathrm{g} / \mathrm{dL}$ at $48 \mathrm{~h}$ but decreased to $3.80 \pm 0.28 \mu \mathrm{g} / \mathrm{dL}$ at $72 \mathrm{~h}$. For $\alpha$-solanidine, NA, CT and simvastatm, the $\mathrm{T}_{4}$ values recorded at $24 \mathrm{~h}$ were $4.00 \pm$ $0.00 \mu \mathrm{g} / \mathrm{dL}$. These values remained the same at $48 \mathrm{~h}$ and $72 \mathrm{~h}$.

Table 2. Effect of aqueous fruit extract of $S$. macrocarpum, nicotinic acid, cholestyramine and simvastatin on thyroid hormones of hyperlipidaemic rats administered triton-X orally for 7 days

\begin{tabular}{|c|c|c|c|c|c|}
\hline \multirow{3}{*}{ Hours after extract/drug administration } & \multirow{3}{*}{$\begin{array}{l}\text { Dosage } \\
\mathrm{mg} / \mathrm{kg}\end{array}$} & \multirow{3}{*}{ Extract/Dug } & \multicolumn{3}{|c|}{ Thyroid Hormones } \\
\hline & & & $\begin{array}{l}\text { TSH } \\
(\mathrm{ng} / \mathrm{mL})\end{array}$ & $\begin{array}{l}\mathrm{T}_{3} \\
(\mathrm{ng} / \mathrm{mL})\end{array}$ & $\begin{array}{l}\mathrm{T}_{4} \\
(\mu \mathrm{g} / \mathrm{dL})\end{array}$ \\
\hline & & & \multicolumn{3}{|c|}{ Mean \pm S.D. } \\
\hline \multirow{6}{*}{24} & 50 & -ve control & $0.45 \pm 0.21^{\mathrm{a}}$ & $0.70 \pm 0.14^{\mathrm{a}}$ & $4.30 \pm 0.43^{\mathrm{a}}$ \\
\hline & 50 & +ve control & $0.30 \pm 0.00^{\mathrm{a}}$ & $0.40 \pm 0.21^{\mathrm{a}}$ & $3.25 \pm 0.35^{b}$ \\
\hline & 50 & Aqueous extract & $0.40 \pm 0.14^{\mathrm{a}}$ & $0.60 \pm 0.14^{\mathrm{b}}$ & $3.60 \pm 0.51^{\mathrm{b}}$ \\
\hline & 50 & A-solanidine & $<0.10$ & $<0.20$ & $4.00 \pm 0.00^{\mathrm{b}}$ \\
\hline & 50 & Nicotinic acid & $<0.10$ & $<0.20$ & $4.00 \pm 0.00^{\mathrm{b}}$ \\
\hline & 50 & Cholestyramine & $<0.10$ & $<0.20$ & $4.00 \pm 0.00^{\mathrm{b}}$ \\
\hline
\end{tabular}




\begin{tabular}{|c|c|c|c|c|c|}
\hline & 50 & Simvastatin & $<0.10$ & $<0.20$ & $4.00 \pm 0.00^{\mathrm{b}}$ \\
\hline \multirow{7}{*}{48} & 50 & -ve control & $0.50 \pm 0.00^{\mathrm{a}}$ & $0.70 \pm 0.12^{\mathrm{a}}$ & $3.60 \pm 0.57^{\mathrm{a}}$ \\
\hline & 50 & +ve control & $0.25 \pm 0.00^{\mathrm{a}}$ & $0.35 \pm 0.07^{\mathrm{b}}$ & $3.25 \pm 0.59^{b}$ \\
\hline & 50 & Aqueous extract & $0.45 \pm 0.00^{\mathrm{a}}$ & $0.65 \pm 0.13^{b}$ & $4.30 \pm 0.43^{b}$ \\
\hline & 50 & $\alpha$-solanidine & $<0.10$ & $<0.20$ & $4.00 \pm 0.00^{\mathrm{b}}$ \\
\hline & 50 & Nicotinic acid & $<0.10$ & $<0.20$ & $4.00 \pm 0.00^{\mathrm{b}}$ \\
\hline & 50 & Cholestyramine & $<0.10$ & $<0.20$ & $4.00 \pm 0.00^{\mathrm{b}}$ \\
\hline & 50 & Simvastatin & $<0.10$ & $<0.20$ & $4.00 \pm 0.00^{\mathrm{b}}$ \\
\hline \multirow{7}{*}{72} & 50 & -ve control & $0.50 \pm 0.28^{\mathrm{a}}$ & $0.65 \pm 0.14^{\mathrm{a}}$ & $3.65 \pm 0.21^{\mathrm{a}}$ \\
\hline & 50 & + ve control & $0.35 \pm 0.07^{\mathrm{a}}$ & $0.30 \pm 0.14^{\mathrm{b}}$ & $2.65 \pm 0.50^{b}$ \\
\hline & 50 & Aqueous extract & $0.40 \pm 0.35^{\mathrm{a}}$ & $0.55 \pm 0.21^{\mathrm{b}}$ & $3.80 \pm 0.28^{b}$ \\
\hline & 50 & $\alpha$-solanidine & $<0.10$ & $<0.20$ & $4.00 \pm 0.00^{\mathrm{b}}$ \\
\hline & 50 & Nicotinic acid & $<0.10$ & $<0.20$ & $4.00 \pm 0.00^{\mathrm{b}}$ \\
\hline & 50 & Cholestyramine & $<0.10$ & $<0.20$ & $4.00 \pm 0.00^{b}$ \\
\hline & 50 & Simvastatin & $<0.10$ & $<0.20$ & $4.00 \pm 0.00^{b}$ \\
\hline
\end{tabular}

+ve control $=$ Rats fed with normal feed diet and had free access to water.

-ve control $=$ Rats fed with normal feed diet and triton-X.

$<0.20 \mathrm{ng} / \mathrm{mL}=$ very low for $\mathrm{T}_{3}$.

$<0.10 \mathrm{ng} / \mathrm{ML}=$ Very low for TSH.

Among groups, mean with different superscripts are statistically significant $(\mathrm{P}<0.05)$.

\subsection{Effect on Testosterone, Oestradiol and Insulin}

The effect of the aqueous fruit extract of S. macrocarpum, $\alpha$ - solanidine, NA, CT and SV on testosterone, oestradiol and insulin are shown in Table 3 . Changes in oestradiol level were significant $(p<0.05)$ throughout the period of study. The level of oestradiol in the negative control was significantly higher $(p<0.05)$ than in the positive control throughout the period of study. For the negative control, the values of oestradiol at 24,48 and 72 $\mathrm{h}$ were $36.50 \pm 2.12 \mathrm{pg} / \mathrm{mL}, 20.00 \pm 4.24 \mathrm{pg} / \mathrm{mL}$ and $24.50 \pm 2.12 \mathrm{pg} / \mathrm{mL}$ respectively, whilst those for the positive control were $15.00 \pm 4.24 \mathrm{pg} / \mathrm{mL}, 13.00 \pm 1.49 \mathrm{pg} / \mathrm{mL}$ and $13.50 \pm 3.54 \mathrm{pg} / \mathrm{mL}$ respectively. The oestradiol levels on extract administration were $18.00 \pm 4.24 \mathrm{pg} / \mathrm{mL}, 19.50 \pm 4.24 \mathrm{pg} / \mathrm{mL}$ and $15.04 \pm 4.24$ $\mathrm{pg} / \mathrm{mL}$ at 24,48 and $72 \mathrm{~h}$ respectively. On administration of $\alpha$-solanidme, NA, CT and SV, the oestradiol levels were too low to be measured i.e. they were $<5.00 \mathrm{pg} / \mathrm{mL}$.

The change in testosterone levels were significant $(\mathrm{p}<0.05)$ at $24 \mathrm{~h}$ and $72 \mathrm{~h}$. The testosterone levels of the negative control were significantly higher $(\mathrm{p}<0.05)$ than those of the positive control throughout the period of study. At 24 and $72 \mathrm{~h}$, the testosterone values for the negative control were $1.50 \pm 0.28 \mathrm{ng} / \mathrm{mL}$ and $1.50 \pm 0.28$ $\mathrm{ng} / \mathrm{mL}$ respectively. On administration of the extract, the testosterone levels were $0.20 \pm 0.07 \mathrm{ng} / \mathrm{mL}$ and $<0.20$ $\mathrm{ng} / \mathrm{mL}$ at $24 \mathrm{~h}, 0.25 \pm 0.00$ at $48 \mathrm{~h}$ and $<0.20 \mathrm{gImL}$ at $72 \mathrm{~h}$. On administration of the extract, the testosterone levels were $0.20 \pm 0.07 \mathrm{ng} / \mathrm{mL}$ and $<0.20 \mathrm{ng} / \mathrm{mL}$ at $24 \mathrm{~h}, 0.25 \pm 0.00 \mathrm{ng} / \mathrm{mL}$ at $48 \mathrm{~h}$ and $<0.20 \mathrm{gImL}$ at $72 \mathrm{~h}$. On administration of $\alpha$-solanidine, NA, CT and SV, the testosterone levels were very low i.e. $<0.20 \mathrm{ng} / \mathrm{mL}$.

Change in insulin level was significant $(p<0.05)$ throughout the period of study. Insulin levels of the negative control were significantly higher $(\mathrm{p}<0.05)$ than those of the positive control throughout the period of study. At 24,48 and $72 \mathrm{~h}$, the insulin values for the negative control were $4.00 \pm 1.41 \mu \mathrm{U} / \mathrm{m} 1,5.00 \pm 0.00 \mu \mathrm{U} / \mathrm{mL}$ and 3.00 $\pm 0.00 \mu \mathrm{U} / \mathrm{mL}$ respectively. On administration of $50 \mathrm{mg} / \mathrm{kg}$ extract, the insulin levels were $2.00 \pm 0.00 \mu \mathrm{U} / \mathrm{mL}$, $1.00 \pm 0.00 \mu \mathrm{U} / \mathrm{ml}$ and $<1.00 \mu \mathrm{U} / \mathrm{mL}$ (i.e. too low to be measured) at 24,48 and $72 \mathrm{~h}$ respectively. On administration of $50 \mathrm{mg} / \mathrm{kg}$ each of $\alpha$-solanidine, NA, CT and SV, the insulin levels remained almost constant throughout the period of study. For $\alpha$-solanidine, the values were $1.50 \pm 0.00 \mu \mathrm{U} / \mathrm{mL}, 2.00 \pm 0.00 \mu \mathrm{U} / \mathrm{mL}$ nd $2.00 \pm 0.00 \mu \mathrm{U} / \mathrm{mL}$ at 24,48 and $72 \mathrm{~h}$ respectively. For NA, the insulin level remained at $2.00 \pm 0.00 \mu \mathrm{U} / \mathrm{mL}$ throughout the study period, for $\mathrm{CT}$, the insulin values were $2.00 \pm 0.00 \mu \mathrm{U} / \mathrm{mL}, 2.00 \pm 0.00 \mu \mathrm{U} / \mathrm{mL}$, and $1.00+$ $0.00 \mu \mathrm{U} / \mathrm{m} 1$ at 24,48 and $72 \mathrm{~h}$ respectively whilst $\mathrm{SV}$ had insulin values of $1.50 \pm 0.00 \mu \mathrm{U} / \mathrm{m} 1,2.00 \pm$ 
$0.00 \mu \mathrm{U} / \mathrm{mL}$, and $2.25 \pm 0.50 \mu \mathrm{U} / \mathrm{mL}$ at 24,48 and $72 \mathrm{~h}$ respectively.

Table 3. Effect of the aqueous fruit extract of S. macrocarpum, nicotinic acid, cholestyramine and simvastatin on testosterone, oestradiol and insulin of hyperlipidaemic rats administered triton-X orally for 7 days

\begin{tabular}{clllll}
\hline Hours after extract/drug administration & $\begin{array}{l}\text { Dosage } \\
\mathrm{mg} / \mathrm{kg}\end{array}$ & $\begin{array}{l}\text { Extract/Dug } \\
50\end{array}$ & $\begin{array}{l}\text { Testosterone } \\
(\mathrm{ng} / \mathrm{mL})\end{array}$ & $\begin{array}{l}\text { Oestrodiol } \\
(\mathrm{pg} / \mathrm{mL})\end{array}$ & $\begin{array}{l}\text { Insulin } \\
(\mu \mathrm{u} / \mathrm{mL})\end{array}$ \\
\hline & 50 & -ve control & $1.50 \pm 0.28^{\mathrm{a}}$ & $36.50 \pm 2.12^{\mathrm{a}}$ & $4.00 \pm 1.41^{\mathrm{a}}$ \\
& 50 & Aqueous extract & $0.20 \pm 0.07^{\mathrm{a}}$ & $\begin{array}{l}15.00 \pm 4.24^{\mathrm{b}} \\
2.00 \pm 0.00^{\mathrm{b}}\end{array}$ & $\begin{array}{l}2.00 \pm 44^{\mathrm{b}} \\
2.00 \pm 0.00^{\mathrm{b}}\end{array}$ \\
& 50 & A-solanidine & $<0.20$ & $<5.00$ & $1.50 \pm 0.00^{\mathrm{b}}$ \\
& 50 & Nicotinic acid & $<0.20$ & $<5.00$ & $2.00 \pm 0.00^{\mathrm{b}}$ \\
& 50 & Cholestyramine & $<0.20$ & $<5.00$ & $2.00 \pm 0.00^{\mathrm{b}}$ \\
& 50 & Simvastatin & $<0.20$ & $<5.00$ & $1.50 \pm 0.00^{\mathrm{b}}$ \\
& 50 & -ve control & $1.55 \pm 0.00^{\mathrm{a}}$ & $20 . .00 \pm 4.24^{\mathrm{a}}$ & $5.00 \pm 0.00^{\mathrm{a}}$ \\
& 50 & +ve control & $<0.20$ & $13.00 \pm 1.49^{\mathrm{b}}$ & $2.50 \pm 0.00^{\mathrm{b}}$ \\
& 50 & Aqueous extract & $0.25 \pm 0.00^{\mathrm{a}}$ & $19.50 \pm 4.24^{\mathrm{b}}$ & $1.00 \pm 0.00^{\mathrm{b}}$ \\
& 50 & $\alpha$-solanidine & $<0.20$ & $<5.00$ & $2.00 \pm 0.00^{\mathrm{b}}$ \\
& 50 & Nicotinic acid & $<0.20$ & $<5.00$ & $2.00 \pm 0.00^{\mathrm{b}}$ \\
& 50 & Cholestyramine & $<0.20$ & $<5.00$ & $2.00 \pm 0.00^{\mathrm{b}}$ \\
& 50 & Simvastatin & $<0.20$ & $<5.00$ & $2.00 \pm 0.00^{\mathrm{b}}$ \\
& 50 & -ve control & $1.50 \pm 0.28^{\mathrm{a}}$ & $24.50 \pm 2.12^{\mathrm{a}}$ & $3.00 \pm 0.00^{\mathrm{a}}$ \\
& 50 & +ve control & $<0.20$ & $13.50 \pm 3.54^{\mathrm{b}}$ & $2.50 \pm 0.07^{\mathrm{b}}$ \\
& 50 & Aqueous extract & $0.25 \pm 0.07^{\mathrm{a}}$ & $15.04 \pm 4.24^{\mathrm{b}}$ & $<1.00^{\mathrm{b}}$ \\
& 50 & $\alpha$-solanidine & $<0.20$ & $<5.00$ & $2.00 \pm 0.00^{\mathrm{b}}$ \\
& 50 & Nicotinic acid & $<0.20$ & $<5.00$ & $2.00 \pm 0.00^{\mathrm{b}}$ \\
& 50 & Cholestyramine & $<0.20$ & $<5.00$ & $1.00 \pm 0.00^{\mathrm{b}}$ \\
& 50 & Simvastatin & $<0.20$ & $<5.00$ & $2.25 \pm 0.50^{\mathrm{b}}$ \\
\hline
\end{tabular}

+ ve control $=$ Rats fed with normal feed diet and had free access to water.

-ve control $=$ Rats fed with normal feed diet and triton-X.

$<0.20 \mathrm{ng} / \mathrm{mL}=$ very low for $\mathrm{T}_{3}$.

$<0.10 \mathrm{ng} / \mathrm{ML}=$ Very low for TSH.

Among groups, mean with different superscripts are statistically significant $(\mathrm{P}<0.05)$.

3.4 Effect of the Aqueous Fruit Extract of S. macrocarpum, $\alpha$-solanidine, Nicotinic Acid, Cholestyramine and Simvastatin on Total Cholesterol of Hyperlipidaemic Rats Administered Triton-X Orally for 7 Days

The effect of the aqueous fruit extract of $S$. macrocarpum, $\alpha$-solanidine and the three hypolipidaemic drugs on total cholesterol of hyperlipidaemic rats are shown in Table 4 . There was a non-significant $(\mathrm{P}>0.05)$ decrease in total cholesterol when compared to the negative control that was administered Triton- $X$ at 24, 48, and 72 hours respectively. 
Table 4. Effect of aqueous fruit extract of $S$. macrocarpum, nicotinic acid, cholestyramine and simvastatin on total cholesterol of hyperlipidaemic rats administered Triton- $X$ for 7 days

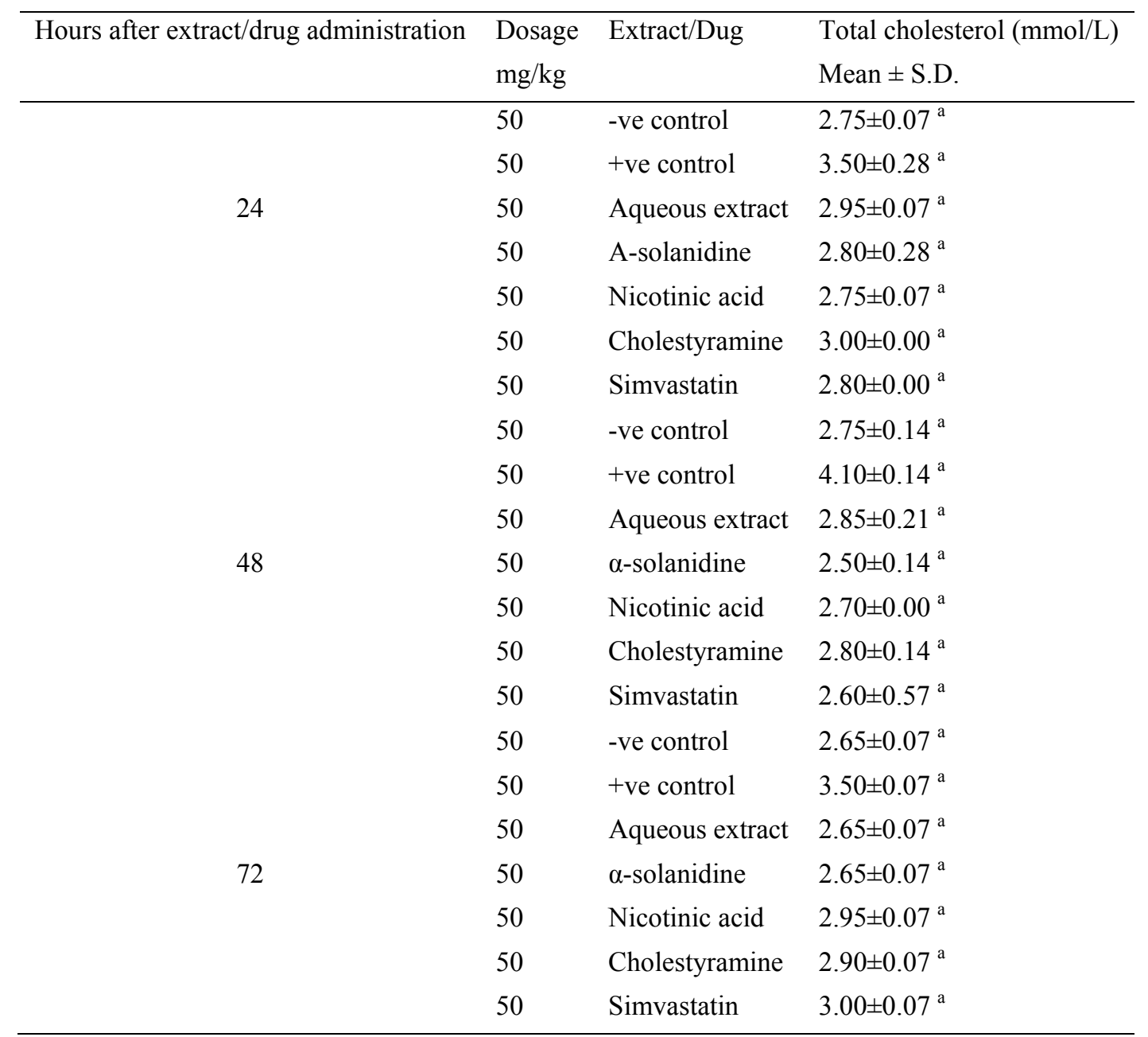

-ve control = Rats fed with normal feed diet and had free access to water.

$+\mathrm{ve}$ control= Rats fed with normal feed diet and triton-X.

Among groups, mean with different superscripts are statistically significant $(\mathrm{P}<0.05)$.

\section{Discussion}

The increase in mean body weight of rats after Triton-X administration for 7 days (Table 1) was statistically significant $(\mathrm{p}<0.05)$ in Groups one, two and five when compared to day zero (i.e. before Triton-X administration). This probably implies that Triton- $X$ at the dosage employed, $400 \mathrm{mg} / \mathrm{kg}$ or for the length of time given, induced hyperlipidaemia, even though differences in the rats' metabolism may account for the differences in the statistics exhibited in their significance.

The hyperlipidaemic rats administered with $50 \mathrm{mg} / \mathrm{kg}$ of the aqueous fruit extract of $S$. macrocarpum had significantly increased $(p<0.05)$ level of the thyroid hormones $T_{3}$ and $T_{4}($ Table 2$)$ when compared to the positive control throughout the study period. There was no change in TSH $(p>0.05)$ throughout the period of study. For the extract, the $T_{3}$ value increased, but for the other four substances, the $T_{3}$ values were too low to be measured i.e. $<0.20 \mathrm{ng} / \mathrm{mL}$. $\mathrm{T}_{4}$ value on extract administration, was higher than that of the positive control, whilst for the other four substances the $\mathrm{T}_{4}$ value remained constant at $4.00 \pm 0.00 . \mu \mathrm{g} / \mathrm{dL}$ throughout the period of study. The $\mathrm{T}_{3}$ values of hyperlipidaemic rats administered $\alpha$-solanidine, NA, CT and SV were all too low to be measured whilst their $\mathrm{T}_{4}$ values remained the same $(4.00 \pm 0.00 . \mu \mathrm{g} / \mathrm{dL})$ throughout the period of study. Increased thyroid hormones lead to increased high density lipoprotein (HDL) which in turn leads to decreased hyperlipidaemia (Sodipo et al., 2012). Also $\mathrm{T}_{3}$, the active hormone, is important in hepatic degradation of cholesterol into bile acid by increasing the transcription of rate-limiting enzymes in the process, the cholesterol 
9-hydroxylase (Gali, 2007; Sodipo et al., 2012). Generally, thyroid hormones are found at lower levels with a high fat diet (Williamson et al., 1996). Thyroid hormones stimulate the synthesis, mobilization and degradation of lipids, (Sodipo et al., 2012). They also lower cholesterol levels (Aliu, 2007). Since, the $50 \mathrm{mg} / \mathrm{kg}$ of the aqueous extract increased $\mathrm{T}_{3}$ and $\mathrm{T}_{4}$ at $24 \mathrm{~h}$ and $48 \mathrm{~h}$, then the plant probably lowers liyperlipidaemia. It has been shown that increased TSH activity occurs on administration of SV after 2 years i.e it has little effect on thyroxine activity (Anonymous b, 2007). CT is not absorbed (Hardman \& Limbird, 2001) so it probably does not have any effect on thyroid hormones. Probably NA and $\alpha$-solanidine also do not have any effect on the thyroid hormones as the values were too low to be determined. However, further work still needs to be carried out on this aspect.

When $50 \mathrm{mg} / \mathrm{kg}$ each of $\alpha$-solanidine, NA, CT and SV were administered to the hyperlipidaemic rats, the level of testosterone was too low to be measured i.e. $<0.20 \mathrm{ng} / \mathrm{mL}$. Probably the dosage or the duration of these substances used was too small to cause any change in the level of testosterone. A study in men administered $20-80 \mathrm{mg} /$ day SV for 12-48 weeks showed a mild decrease in testosterone level (Anonymous $b, 2007$ ). Since the SV was only estimated at 24,48 and $72 \mathrm{~h}$ post administration, then a change in the testosterone level might not be detected. The same thing may apply to $\alpha$-solanidine and NA. CT is not systemically absorbed (Hardman and Limbird, 2001), so changes in endocrine function may not occur. The significant increase $(p<0.05)$ in testosterone observed at $24 \mathrm{~h}$ and $72 \mathrm{~h}$ on administration of the extract to the hyperlipidaemic rats may be due to a combination of phenolics like flavonoids and tannins (Sodipo et al., 2008) found in the fruit of S. macrocarpum. Some studies suggest that antioxidants like flavonoids and tanins are less effective when isolated from food and presented in tablet form (Khan, 2008). Thus, it may be possible that the active glycoalkaloid, $\alpha$-solanidine and the three hypolipidaemic drugs could not have the same effect when taken singly than if the extract was administered alone.

When the hyperlipidaemic rats were administered with the $50 \mathrm{mg} / \mathrm{kg}$ extract, there was a significant rise $(\mathrm{p}<0.05)$ in the $17 \beta$-oestradiol level at $24 \mathrm{~h}$ and $48 \mathrm{~h}$. Oestradiol levels have been shown to be decreased in patients with myocardial infarction (Odutola, 1992; Williamson et al., 1996; Sodipo et al., 2012). The increase in oestradiol on administration of $50 \mathrm{mg} / \mathrm{kg}$ extract at $24 \mathrm{~h}$ and $72 \mathrm{~h}$ implies therefore that the hyperlipidaemia is probably being reduced by the aqueous fruit extract of $S$. macrocarpum. In fact, oestrogens have been shown to decrease low density lipoprotein cholesterol (LDL-C) by 5-10\% (Anonymous, 2008; Sodipo et al., 2012). On administration of a-solanidine, NA, CT and SV to the hyperlipidaemic rats, the oestradiol levels were too low to be measured i.e. $<5.00 \mathrm{pg} / \mathrm{mL}$. CT is not systemically absorbed, (MacDonald et al., 2005) so it may not affect endocrine function indices. The $\alpha$-solanidine, nicotinic acid and SV are single entities and it is probable that their effect may not be as strong as if a combination of active principles are present in a single plant (Khan, 2008), like it occurs in the fruit of $S$. macrocarpum.

When the hyperlipidaemic rats were treated with $50 \mathrm{mg} / \mathrm{kg}$ extract, there was no rise in the insulin level, instead it significantly decreased $(\mathrm{p}<0.05)$ from $2.00 \pm 0.00 \mu \mathrm{U} / \mathrm{mL}$ at $24 \mathrm{~h}$ to $1.00 \pm 0.00 \mu \mathrm{U} / \mathrm{mL}$ at $48 \mathrm{~h}$ and to $<1.00$ $\mu \mathrm{U} / \mathrm{mL}$ at $72 \mathrm{~h}$ (i.e, it was too low to be measured). Probably, the $50 \mathrm{mg} / \mathrm{kg}$ extract dose was too low to reverse the effect of the triton-induced hyperlipidaemia. Also, with time, probably the effect of the extract could no longer be felt as there was a decrease in the level of insulin with increase in time i.e. from $24 \mathrm{~h}$ to $48 \mathrm{~h}$ and finally to $72 \mathrm{~h}$ of study. When the hyperlipidaemic rats were administered with $50 \mathrm{mg} / \mathrm{kg} \alpha$-solanidine and the three hypolipidaemic drugs, the level of insulin remained almost constant at $2.00 \pm 0.00 \mu \mathrm{U} / \mathrm{mL}$, close to the value obtained with the hyperlipidaemic rats, implying probably that at $50 \mathrm{mg} / \mathrm{kg}$, these substances are not very effective at increasing insulin level in hyperlipidaemic rats, thus conversion of VLDL and chylomicrons to triglycerides for utilization cannot be increased as the enzyme responsible for conversion of VLDL and chylomicrons to triglycerides is increased by insulin and thyroxine (Hardman \& Limbird, 2001) and since the level of insulin has not been found to be increased by these substances at the dosage employed, then they probably were not effective in lowering hyperlipidaemia.

\section{Conclusion}

The aqueous fruit extract of $S$. macrocarpum when compared to $\alpha$-solandine, CT, SV and NAunder the condition of study was probably more effective in lowering hyperlipidaemia in the triton $\mathrm{X}$ induced hyperlipidaeimc rats as the fruit is a combination of active principles whilst the other four substances are single entities.

\section{Acknowledgements}

The authors gratefully acknowledge the technical assistance of Mr. Fine Akawo of Chemistry Department, University of Maiduguri and Mr. Kolawole Akindoyin (Chief Medical Laboratory Scientist, Chemical Pathology) University of Maiduguri Teaching Hospital, for hormonal analysis. The University of Maiduguri is also appreciated for the research grant and fellowship granted to the first author. 


\section{References}

AIiu, Y. O. (2007). Endocrine Pharmacology Veterinary Pharmacology. (1st ed.). Tamaza Pub. Co. Ltd Zaria, Nigeria. pp. 282-341.

Anonymous a. (2007). Solasodine. Retrieved from http://www.chendel.com/products/solasodine.htm

Anonymous b. (2007). Arrow-Simvastati. Retrieved from http://www.medsafe.gov.nz/profs/Datasheet/Arrow SVtab.htm

Anonymous. (2008). WO/1996/021443. Use of 3, 4-Diphenyl chromans for the manufacture of a pharmaceutical composition for the treatment of prophylaxsis of hyperlipoproteinaemia, hypertriglyceridaemia, hyperlipidaemia or hypercholesterolaemia or arteriosclerosis or for anticoagulative treatment. Retrieved from http://www.wipo.intpctdb/en/wo.jsp? 1 A=Dk 1996000014 \& DISPLAYDESC. Access date: $25 / 11 / 2008$.

Bravermann, L. E. (1996). Evaluation of thyroid status in patients with thyrotoxiconsis Clinical Chemistry., 42, 174-181.

Chopra, I. J., Hershman, J. M., Pardridge, W. M., \& Nicoloff, J. T. (1971a). A radio immune assay of thyroxine. Journal of Clinical Endocrinologhy, 33, 865-869. http://dx.doi.org/10.1210/jcem-33-5-865

Chopra, I. J., Hersliman, J. M., Pardridge, W. M., \& Nicoloff, J. T. (1971b). A radio immune assay of triiodothyronine Journal of Clinical Endocrinology, 33, 870-874.

CIOMS. (1985). Council of International Organizations of Medical Sessions. International Guiding Principles for Biochemical Research Regarding Animals \% WHO K2 11. Geneva 27, Switzerland.

Evans, A., \& Stein, M. D. (1986). Textbook of Clinical Chemistry (Tietz, N. W. Eds.). WH Sanders Co. Philadelphia. pp. 884-887.

Fernando, M. R. Wickramansingbe, S. M. D., Nalinle, I., Thabrew, M. L., Ariyanando, P. T., \& Karunanayake, E. H. (1991). Effects of Artocarpus heterophyllus and Aesterachantus longifolia on glucose tolerance in normal subjects and in maturity-onset diabetic patients. Journal of Ethnopharmacology, 31, 277-283. http://dx.doi.org/10.1016/0378-8741(91)90012-3

Fisher, D. A. (1996). Physiological variations in thyroid hormones. Physiological and pathological considerations. Clinical Chemistry., 42, $135-139$.

Gali, R. M. (2007). Lipid profile in patients with thyroid diseases attending University of Maiduguri Teaching Hospital in North Eastern Nigeria. M.Sc Dissertation, University of Maiduguri Nigeria, p. 60

Graph Pad Software. (1998). Graph Pad Software, Inc. San Diego, California, U.S.A. www.graphpad. com

Grubben, G. J. H., \& Denton, O. A. (2004). PROTA 2. Plant Resources of Tropical Africa 2 Vegetables. Ponen and Looijen hv, Wagening en, Netherlands, p. 661

Hardman, J. G., \& Limbird, L. E. (2001). Drug therapy for hyperlipidaemia and dyslipidaemia. Goodman and Gilmans The Pharmacologic Basis of Therapeutics (10th ed.). McGraw-Hill Co. USA, pp. 971-1001.

Hopton, M. R., \& Harrap, J. J. (1996). Immunoradiometric assay of thyrotropin as a first line thyroid function test in the routine laboratory. Clinical Chemistry, 32, 691- 698.

Khan, I. Z. (2008). Antioxidant Therapy- Antioxidant Help you Fight Disease. Heal with Herbs. pp. 1-4 (Unpublished).

Lin, J., Opuku, A. R., Gaheeb-Keller, M., Hutchings, A. D., Terbianche, S. E., Jager, A. K., \& Vans-Starden (1999). Preliminary screening of some traditional Zulu medicinal plants for anti-inflammatory and $\begin{array}{lllll}\text { anti-bacterial activities. Journal of Ethnophamacology, 68, } & \text { 2674. }\end{array}$ http://dx.doi.org/10.1016/S0378-8741(99)00130-0

MacDonald, R. S., Guo, J., Copeland, J., Browning Jr, J. D., Sleper, D., George, E. R., \& Berhow, M. A. (2005). Environmental influences on isoflavones and saponin in soya beans and their role in colon cancer. Journal of. Nutrition, 135, $1239-1242$.

Mittal, C. C., Aguwa, C. N., Ezeinu, B. U., \& Akubue, P. I. (1981). Preliminary pharmacological studies. on antivenom action of Diodia scandens leaves. Nigerian Journal of Pharmacy, 2, 432-436.

NIH. (1990). National Institute of Health. Recommendations for 'Improving cholesterol measurement. A Report from the Lab Standardization Panel of the National Cholesterol Education Programme. NIH Publication No. 
90-2564.

Odutola, A. A. (1992). Rapid Interpretation of Routine Clinical Laboratory Tests. J. Asekome and Company, Zaria, p. 112.

Sodipo, O. A., Abdulrahman, F. I., Akan, J. C., \& Akinniyi, J. A. (2008). Phytochemical screening and elemental constituents of the fruit of Solanum macrocarpum Linn. Continental Journal of Applied Science, 3, 88-97.

Sodipo, O. A., Abdulrahman, F. I., Sandabe, U. K. \& Akinniyi, J. A. (2009a). Effects of the aqueous fruit extract of Solanum macrocarpum Linn. on some haematological indices in albino rats fed with cholesterol-rich diet. Sahel Journal of Veterinary Science, 8(2), 5-12.

Sodipo, O. A., Abdulrahman, F. I., Sandabe, U. K., \& Akinniyi, J. A. (2009b). Effect of Solanum macrocarpum Linn. on biochemical liver function in diet-induced hypereholesterolaemie rats. Nigerian Veterinary Journal, $30(1), 1-8$.

Sodipo, O. A., Abdulrahman, F. I., Sandabe, U. K., \& Akinniyi, J. A. (2011) Biochemcial liver function with aqueous fruits extract of Solanum macrocarpum Linn in albino rats acutely administered triton-X to induce hyperlipidemia. Journal of Applied Pharmaceutical. Science, 1(8), 89-93.

Sodipo, O. A., Abdulrahman, F. I., Sandabe, U. K., \& Wampana, B. (2012). Endocrine function with aqueous fruit extract of Solanum macrocarpum Linn. In albino rats chronically administered Triton-X to induce hyperlipidemia. International Organic and Scientific Research Journal of Pharmacy, 2(3), 464-474.

Sood, R. (2006). Textbook of Medical Laboratory Technology (1st ed.). Jaypee Brothers Medical Publishers (p) New Delhi, India. pp. 192- 672.

Tsang, B. K., Armstrong, D. T., \& Whitfield, J. F. (1980). Steroid biosynthesis by isolated human ovarian follicular cell in vivo Journal Clinical. Endocrinology and. Metabolism, 51, 1407-1411. http://dx.doi.org/10.1210/jcem-51-6-1407

Williamson, E. M., Opako, D. T., \& Evans, F. J. (1996). Pharmacological Methods in Phytotherapy Research. Vol. 1. Selection, Preparation and Pharmacological Evaluation of Plant Material. Wiley and Sons, England, p. 228. 